\title{
Social Relationships in Conversational Interaction: Comparison of Learner-Learner and Learner-NS Dyads
}

\author{
Masatoshi Sato \\ Human International Universities and Colleges \\ Consortium
}

This study investigates interactional moves of Japanese EFL learners and how they modify their oral output differently depending on whether their interlocutor is a peer or a native speaker (NS). By employing retrospective stimulated recall methodology, this study also explores the participants' perceptions which arguably determined their interaction patterns during a communicative task. Participants were eight Japanese first-year university students and four NSs of English. Conversations of eight learner-NS dyads and four learner-learner dyads (six hours in total) were audiotaped, transcribed, and then statistically analyzed. Learners were interviewed two days after task completion. Results revealed that learners interacted in significantly different ways depending on whom they interacted with. Integrating the introspection data from stimulated recall sessions, this study provides social and cultural perspectives to the research field of interaction; specifically, social relationships have significant influences on interaction patterns.

本稿は、日本人英語学習者が、英語での会話の中で相手に誤解を生じさせるような発言をし た場合、また文法的な間違いを犯した場合に、その会話の相手が日本人英語学習者であるか、 英語を母語とする者であるかによって、修正の方法を変えるのかどうか、また変えるとすればど のように変えるのかを探るものである。統計的分析に加えて、面接調査を行いやりとりの型を決 定付けたと想定される話し手の会話中の心理を考察した。調査対象は日本人の大学 1 年生 8 名および英語の母語話者 4 名であった。日本人学習者と英語母語話者のペア 8 組、および学習 者同士のペア 4 組(合計 6 時間分)の会話を録音し、文字化した。さらに 2 日後に各学習者に面 接を行った。統計分析を行った結果、学習者は会話の相手によって、有意に異なる会話パターン

JALT Journal, Vol. 29, No. 2, November, 2007 
を選択することが明らかにされた。統計分析、面接、リコール (stimulated recall)などによって得 られた結果を統合することにより、本稿では会話における相互作用の文化的、社会的側面に焦 点を当てた。特に社会的な人間関係が会話のパターンに大きく影響することを明らかにした。

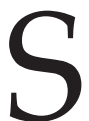

ince the 1970s, researchers in the field of second language acquisition (SLA) have endeavoured to understand the various components of communicative competence and how they interact to drive second language (L2) development forward (Canale \& Swain, 1981). A great number of researchers have conducted studies, including experimental (Gass \& Varonis, 1985, 1994; Mackey \& Philp, 1998; Nobuyoshi \& Ellis, 1993; Pica, Young, \& Doughty, 1987; Van den Branden, 1997), classroom experimental (Doughty \& Varela, 1998; Foster, 1998; Muranoi, 2000, 2001; Swain \& Lapkin, 1998, 2002), and classroom observational ones (Doughty \& Pica, 1986; Lyster \& Ranta, 1997; Pica, 2002; Storch, 2001, 2002) to investigate how language learners develop their speaking skills through interaction with other learners, native speakers (NSs) of the target language, or language teachers. Important to mention is that there have been some studies that were designed to compare two types of interaction: learners-learners and learners-NSs (e.g., Futaba, 2001; Mackey, Oliver, \& Leeman, 2003; Pica, Lincoln-Porter, Paninos, \& Linnell, 1996; Shehadeh, 1999, 2001, 2003; Varonis \& Gass, 1985). It is both theoretically and pedagogically important to investigate these interactions because the findings have the potential to contribute to the design of classroom activities in a way that will allow learners to improve their communicative abilities in foreign languages. Thus, one of the goals of the present study is to reveal learners' different types of interactional moves depending on their interlocutor, namely another learner or a NS, by focusing on how they notice and modify their grammatically inaccurate utterances.

The present study investigates Japanese English as a Foreign Language (EFL) learners, who in general have a well known but insufficiently investigated language learning issue: despite the length of time during which they receive English instruction, they generally end up as faulty comprehenders and nonfluent speakers while often being considered good readers and writers (e.g., Block, 2003). This educational problem can be discussed from various perspectives. A widespread and ongoing teaching method, namely the grammar-translation method, is an issue because it does not necessarily focus on learning communicative skills (DeKeyser, 1998), and it impedes proceduralization of declarative knowledge (i.e., grammatical knowledge) in oral production (Anderson, 1990; de Bot, 
1996; Skehan, 1998). The linguistic environment is also an issue in that learners have limited exposure to the target language (Bardovi-Harlig \& Dörnyei, 1998; Robinson, Sawyer, \& Ross, 2001; Wilkins, 1999). Another issue can be the socioeducational environment wherein English is taught as a subject in the scheme of a test-driven society, and also where learners are not encouraged to speak up in classrooms (Kess, 1996; Lee, 1999). Taking these language learning issues into consideration, by employing retrospective stimulated recall methodology, the present study investigates the social and cultural dimensions of why learners use different interactional moves depending on their interlocutors.

\section{Background}

Many researchers who support the argument that interaction can facilitate L2 learning claim that conversational interaction is effective because learners try to solve communication problems by engaging in negotiation of meaning (Gass, 1997; Long, 1996; Pica, 1994). Other researchers, however, claim that negotiation of meaning is not enough to help learners improve their grammatical accuracy (Lyster, 1998, 2002a; Spada, 1997; Spada \& Lightbown, 1993; Swain, 1998). They claim that in order to improve accuracy, learners should negotiate not only for meaning but also for form. In so doing, learners can notice the "hole[s]" in their interlanguage (Swain, 1995), and sometimes they can correct their erroneous utterances themselves with the aid of corrective feedback.

A large number of studies have examined Long's $(1981,1996)$ "interaction hypothesis" (e.g., Doughty \& Pica, 1986; Gass \& Varonis, 1989; Pica et. al., 1987). These studies have investigated to what extent conversational interaction is effective for language learners' interlanguage development in communicative contexts: specifically, how conversational interaction works to make input comprehensible, provide learners with certain types of feedback, and make learners' output more comprehensible. The underlying assumption of these studies is that in interaction involving a learner and "a NS or a more competent" (Long, 1996) speaker of the target language, communication breakdowns naturally occur. In the process of solving the communication problem and attempting to reach mutual understanding, learners and their interlocutors negotiate meaning. In other words, what triggers negotiation, which is theoretically related to subsequent interlanguage development (Schmidt \& Frota, 1986), is always a communication breakdown. 
Considering Swain's (1985) argument that once they have acquired communicative skills that satisfy classroom interaction with their teacher or their peers, Canadian immersion students tend to stop developing their grammatical accuracy, Lyster (2002b) proposed that negotiation of meaning is "too narrow a construct to fulfill its pedagogical potential in teacher-student interaction in communicative and content-based second language (L2) classrooms" (p. 237). Lyster stresses the importance of negotiation of form because it has a pedagogical function: to focus learners' attention on form, and it aims for both accuracy and mutual understanding. Lyster and Ranta (1997) found that when they interact with students, teachers often feign incomprehension to intentionally draw learners' attention to nontarget-like form. The effectiveness of this move lies in pushing learners to "notice a gap" (Schmidt \& Frota, 1986) between their interlanguage form and the target form, thus encouraging them to modify their output. Therefore, these two types of negotiation should be differentiated in the sense that while negotiation of form is derived from a language teacher's intentional feedback on a learner's erroneous utterances to push the learner to modify his/her output, the negotiation of meaning generally stems from unintentional interactional feedback on the learner's incomprehensible utterances to solve a communication breakdown.

With respect to learners' modification of their incomprehensible and / or inaccurate utterances, research has shown that language production gives learners the opportunity to expand their interlanguage capacity by reprocessing and restructuring their utterances after noticing a problem, which triggers "mental processes that lead to modified output" (Swain \& Lapkin, 1995, p. 373). Interesting to mention here is that some studies have reported that learners are capable of negotiating form even in peer interaction, and moreover, of modifying their erroneous utterances in the context of conversational interaction by pointing out and solving linguistic problems together (e.g., Foster \& Ohta, 2005; McDonough \& Mackey, 2000; Storch, 2001, 2002, but see Van den Branden, 1997).

McDonough and Mackey (2000) conducted a study motivated by an ongoing debate in SLA, that is, whether or not learners are able to draw each other's attention to linguistic forms through negotiating for meaning (see Pica, 1994; Seedhouse, 1997). The researchers found that the learners were able to talk about certain linguistic forms while engaging in communicative tasks even though there was mutual understanding between them already. However, as they state, the researchers aimed "to design tasks that provided learners with opportunities to pay attention 
to linguistic form in the context of meaning" (p. 85). Therefore, the participants succeeded in negotiating for form and meaning at the same time because of the tasks, which were designed to encourage the learners to talk about certain forms: noun classifiers in this particular study. This negotiation of form is identical to Swain's (1998) "metatalk," in which learners are naturally encouraged to talk about particular linguistic features while engaging in certain types of tasks, but different from Lyster's (2002b) negotiation of form in which a teacher's intervention triggers an extra sequence on language problems without breaking the communicative flow.

The studies cited above have investigated what linguistic features a learner notices during interaction and how, and have operationalized modified output as a sign of noticing (see also Ellis, Basurkmen, \& Loewen, 2001; Panova \& Lyster, 2002), whereas other studies have tried to reveal what features language learners notice by analyzing their introspection. To investigate learners' interaction patterns in general, some researchers claim that solely quantifying utterances is not enough (Cohen, 1987; Corder, 1973). In fact, research has revealed that learners' oral production does not fully represent their interlanguage (e.g., Hawkins, 1985; Poulisse, Bongaerts, \& Kellerman, 1987).

In this vein, by employing stimulated recall, Mackey, Gass, and McDonough (2000) examined how learners perceive feedback and its target, that is, what feedback is being provided for, and whether their perceptions affect their noticing. Comparing the amount of feedback on morphosyntactic errors and stimulated recall comments on these language-related episodes, the researchers found that the learners' opportunities to notice grammatical features in interaction was relatively small. Nabei and Swain (2002) provided a different perspective which was discovered through stimulated recall sessions: they revealed that what and how a learner noticed while she was in class was a complex learning behavior influenced by the teaching environment, the interactional context, and the learner's cognitive orientation. Morris and Tarone (2003) also revealed that learners' perceptions of their interlocutors significantly influenced their choice of interactional moves. In their study, it was found that interpersonal conflict and negative social interaction between the students significantly affected the perceptions of feedback. These studies are of importance in that they showed that language learning behavior, specifically noticing, can be significantly affected by social relationships between interactants (see Bell, 1984). 


\section{Research Questions}

Drawing on the results of the research to date, the following research questions were formulated:

1. How do learners and NSs react to grammatically inaccurate utterances in conversational interaction?

2. To what extent do learners modify their inaccurate utterances in response to their interlocutors' feedback?

3. How do learners' perceptions of their partners influence their interactional moves?

\section{Method}

\section{Participants}

Participants were eight Japanese EFL learners (three males and five females; all names appearing in this paper are pseudonyms) and four NSs (four males). A questionnaire was distributed to 151 students, aged 18-19, attending required freshman EFL classes at a prestigious university in Japan. The questionnaire was designed to ensure a relatively homogeneous sample of typical Japanese EFL learners who had neither spent a significant amount of time living or studying in an English-speaking country. From the students who met these criteria, eight learner participants were randomly selected. Of the four NSs who participated in the present study, all were university students whose ages ranged from 21 to 23; three were from Australia and one was from Canada. None of the NSs had any formal training or experience teaching English. By virtue of not being trained teachers, the NSs in the present study were similar in background to the Assistant Language Teachers (ALTs) usually involved in the Japanese Exchange and Teaching (JET) program.

\section{Procedures}

To compare learners' interactional moves in learner-learner dyads with those in learner-NS dyads, the participants were paired in four learnerlearner dyads and eight learner-NS dyads. Each of the four learners who interacted with each other had a different NS interlocutor, thus meeting conditions for statistical analyses of learners' interactional moves (see Welkowitz, Ewen, \& Cohen, 2001). To facilitate data collection, learners were randomly assigned to one of two groups. Group 1 included four learners who interacted in learner-learner dyads at Time 1 and then in 
learner-NS dyads at Time 2. Group 2 included four learners who interacted in learner-NS dyads at Time 1 and then in learner-learner dyads at Time 2. This design was intended to decrease interlocutor familiarity (Plough \& Gass, 1993). Two similar two-way information-gap tasks were used so that each participant completed different tasks at Times 1 and 2, as shown in Table 1.

Table 1. Composition of learner-learner and learner-NS dyads at Times 1 and 2

\begin{tabular}{|c|c|c|c|}
\hline & Time 1 - Task 1 & \multicolumn{2}{|c|}{ Time 2 - 7} \\
\hline Group 1 & $\begin{array}{l}\text { Learner } 1 \Leftrightarrow \text { Learner } 2 \\
\text { Learner } 3 \Leftrightarrow \text { Learner } 4\end{array}$ & $\begin{array}{l}\text { Learner } 1 \Leftrightarrow \mathrm{NS} 1 \\
\text { Learner } 2 \Leftrightarrow \mathrm{NS} 2\end{array}$ & $\begin{array}{l}\text { Learner } 3 \Leftrightarrow N S 3 \\
\text { Learner } 4 \Leftrightarrow N S 4\end{array}$ \\
\hline Group 2 & $\begin{array}{ll}\text { Learner } 5 \Leftrightarrow \mathrm{NS1} & \text { Learner } 7 \Leftrightarrow \mathrm{NS3} \\
\text { Learner } 6 \Leftrightarrow \mathrm{NS} 2 & \text { Learner } 8 \Leftrightarrow \mathrm{NS4}\end{array}$ & $\begin{array}{l}\text { Learner } 5 \Leftrightarrow \\
\text { Learner } 7 \Leftrightarrow\end{array}$ & $\begin{array}{l}\Rightarrow \text { Learner } 6 \\
\text { Learner } 8\end{array}$ \\
\hline
\end{tabular}

In a two-way information exchange task using pictures, both participants in a dyad hold the same amount of information so that each has to provide his or her interlocutor with accurate descriptions of the pictures to complete the task. For each task in the present study, each participant held three pictures and described them to the interlocutor. Therefore, there were six pictures in total with clues indicating the timeline of an event. Using the information that they obtained from each other, they worked together to put the six pictures in chronological order. Thus, it was expected that there would be a two-way flow of requests for and offering of information, without either interlocutor doing all the talking and dominating the conversation (see Pica, Kanagy, \& Falodun, 1993). During the tasks, participants sat on chairs facing each other at a table without any partition. They completed the task in English without looking at each other's pictures. The conversations, which varied from 20 to 30 minutes, were recorded with digital audio recorders.

\section{Coding}

To code the interaction data, language-related episodes were identified in which participants either negotiated for meaning or engaged in conversation that started with grammatically inaccurate utterances (see Swain \& Lapkin, 1998, 2002; Williams, 1999). The present study specifically 
focused on language-related episodes that concern grammatical accuracy. Grammatically inaccurate utterances were identified whether or not they generated language-related episodes; cases where erroneous utterances did not generate language-related episodes were coded as abandonment. In terms of the repair moves of the learners, only successful repairs were coded as modifications. Adapting coding schemes by Pica et al. (1996, see also Shehadeh, 1999, 2001, 2003; Varonis \& Gass, 1985), I coded languagerelated episodes as a sequence of three interactional moves: triggers, feedback, and responses. Table 2 identifies these three coding categories and their component subcategories used to analyze language-related episodes. In addition, other interactional moves such as self-initiated modified output and repetitions without rising intonation were also statistically analyzed (examples appear in the Results and Discussion). In the present study, I analyzed learners' interactional moves as dependent variables and learners' interlocutors as an independent variable. In so doing, I explored how differently learners interact depending on whether their interlocutor is another learner or a NS. T tests for matched samples with an alpha level of .05 with the use of a Bonferroni adjustment were employed to analyze learners' interactional moves across dyad types.

To ensure the reliability of the coding procedure, I trained another researcher who was also a native speaker of Japanese with native-like proficiency in English to code data according to the coding categories. Following the training sessions, the second rater independently coded a randomly selected subsample of $15 \%$ of the transcriptions. This test of interrater reliability yielded a simple percentage agreement level of $93 \%$, which was considered reliable.

\section{Retrospective Stimulated Recall}

During the two days following task completion, I transcribed the oral interaction data and then conducted a retrospective stimulated recall session with each learner during which the learners were asked what linguistic features they noticed, why they acted in certain ways, and what their perceptions were while engaging in the task. Participants listened to the audio recordings of their oral interaction as I asked questions about specific language exchanges and about their perceptions. Participants were also encouraged to ask me to stop the recording at any time and comment on whatever they noticed in the conversation (for a methodological discussion, see Ericsson \& Simon, 1984; Gass \& Mackey, 2000; Mackey, 2002). The stimulated recall sessions were conducted in 
Table 2. Coding categories for interactional moves in language-related episodes

Triggers

- Trigger stemming from incomprehensibility

- Trigger stemming from inaccuracy

Feedback

- Elicitation

- Clarification request

- Confirmation request without modification of trigger

- Nonverbal signal

- Reformulation

- Recast

- Confirmation request with modification of trigger

Responses

- Modified output

- Modification of trigger with incorporation of feedback

- Modification of trigger without incorporation of feedback

- Nonmodified output

- Repetition of trigger

- Acknowledgement

- Topic continuation

- Inability to respond

- Feedback ignored

Japanese and lasted approximately one hour for each participant. (The retrospection data was translated by the author, and original excerpts in Japanese from sessions are shown in the Appendix.)

\section{Results and Discussion}

\section{Negotiation of Form in Conversational Interaction}

To answer the first research question, which asked how learners and NSs react to grammatically inaccurate utterances, the proportions of trig- 
gers stemming from inaccurate utterances relative to the total number of grammatically inaccurate utterances were compared. This analysis investigates (a) how often learners had opportunities to repair grammatical errors by engaging in language-related episodes, and (b) the proportional differences of these opportunities depending on the type of dyad. As shown in Table 3, when learners interacted with other learners, they made 55 grammatical errors of which $17(31 \%)$ generated languagerelated episodes. The remaining $69 \%$ were coded as abandonment and thus remained errors. A similar result was obtained in learner-NS dyads where they made 56 grammatical errors and $18(32 \%)$ of these generated language-related episodes. These differences were not statistically significant.

Table 3. Opportunities to repair grammatical errors across dyad types

\begin{tabular}{lcccc}
\hline & \multicolumn{2}{c}{ Learner-NS dyads } & \multicolumn{2}{c}{ Learner-learner dyads } \\
\cline { 2 - 5 } & $\mathrm{n}$ & $\%$ & $\mathrm{n}$ & $\%$ \\
\hline Triggers & 18 & 32 & 17 & 31 \\
Abandonment & 38 & 68 & 38 & 69 \\
\hline Total (GI) & 56 & 100 & 55 & 100 \\
\hline
\end{tabular}

Note. GI=Grammatically inaccurate but comprehensible utterance

The previous research has found that learners are not always able to reach grammatical accuracy when they try to solve a linguistic problem, simply because they do not yet have correct forms in their interlanguage (Gass \& Varonis, 1989). While the same phenomenon was observed in the present study, a new finding was that this was the case not only in learnerlearner dyads but also in learner-NS dyads. Although the present study did not investigate whether or not the outcomes of the language-related episodes were successful, it revealed by statistically comparing the two types of dyads, that the probability of reaching grammatical accuracy when learners make errors is proportionally the same in both types of dyads.

Concerning the question of whether or not second or foreign language learners negotiate for form in a conversational interaction environment, the analysis showed that negotiation of form was not observed either in the learner-learner dyads or in the learner-NS dyads (see Van den 
Branden, 1997). Here, I would like to clarify the context of the present study because I believe learning behaviors significantly vary depending on contexts. Therefore, for several reasons, I do not mean to generalize the findings to other contexts. First, unlike classroom studies (e.g., Ellis et al., 2001; Lyster \& Ranta, 1997), the NSs were not trained teachers and the research was not conducted in a classroom setting. Second, the participants were not instructed to do anything specific other than to work together to complete the task; therefore, interaction was totally conversational (cf. Muranoi, 2000, 2001). Finally, the information gap task in the present study was not intended to elicit any particular forms (cf. McDonough and Mackey, 2000).

As shown in Table 4, from the learners' perspective in learner-NS dyads, most of the feedback provided by NSs following grammatically inaccurate utterances was reformulation that provided correct forms (91\%). Therefore, it is likely that these reformulation moves, which mostly consisted of recasts, were too ambiguous for learners to be stimulated to notice a gap between what they produced and what they heard. In addition, NSs' feedback was not intended to push learners to correct the error, so there were many instances where learners did not have an opportunity to react to the reformulation feedback; many reformulation moves were embedded in sentences which required other types of responses such as a topic continuation rather than modified output (see Nicholas, Lightbown, \& Spada, 2001). This was also the case in learner-learner dyads. Although learners gave feedback following grammatically inaccurate utterances, all of the instances were reformulation moves (100\%; see Table 4).

The stimulated recall sessions revealed that the learners' feedback following grammatically inaccurate utterances was not intended as corrective feedback. Even in exchanges such as excerpt 1, in which Mariko seems to be recasting very intentionally, she reported that she was simply confirming the message by recasting Aya's erroneous utterances.

\section{Excerpt 1}

Aya: E picture, people is... people is... [1nid]

Mariko: Riding?

Aya: Riding bus.

Mariko: Riding on the bus?

Reflecting on this exchange, Mariko said, "I was just confirming because Aya looked like she was not sure. I never meant to correct her errors. I was 
Table 4. Feedback types following inaccurate utterances

\begin{tabular}{llllll}
\hline & \multicolumn{2}{c}{ Learner } & & \multicolumn{2}{c}{ NS } \\
\cline { 2 - 5 } Feedback types & $\mathrm{n}$ & $\%$ & $\mathrm{n}$ & $\%$ \\
\hline
\end{tabular}

\section{Elicitation}

Clarification request

Confirmation request without modification of trigger

Nonverbal signal

$0 \quad 0$

0

0

$\begin{array}{llll}0 & 0 & 4 & 9\end{array}$

$\begin{array}{llll}0 & 0 & 0 & 0\end{array}$

$\underline{\text { Reformulation }}$

Confirmation request with modification of trigger

Recast

$\begin{array}{rrrr}16 & 94 & 32 & 75 \\ 17 & 100 & 43 & 100\end{array}$

simply confirming the message whenever I repeated her" (Retrospection excerpt 1; see Appendix for the original Japanese).

Interestingly, however, there was one instance where a learner told me that he recast intentionally (Excerpt 2). Shigeo told me that he noticed his partner's grammatical error and gave him the corrected version to let him know.

\section{Excerpt 2}

Daisuke: F!F!F! No, sorry!!! Two bus... there is two bus.

Shigeo: Two bus? Two buses. Two bus...two buses...two buses.

Daisuke: Yes. Ah... perhaps.

In the stimulated recall session, Shigeo told me that, "I heard that Daisuke said 'two bus,' and then I thought that was not right. I said 'two buses' because I wanted to let him know that he needed to pluralize it" (Retrospection excerpt 2). Although this was the only instance where a participant told me that his corrective feedback was intentional, it is particularly interesting in light of the question of whether or not learners negotiate for 
form in conversational interaction. It seems that his intention was to attempt negotiation of form because his feedback was not aimed at achieving mutual understanding; rather it was an extra sequence to talk about a specific form with his partner although it did not generate negotiation of form.

I would like to claim that language learners are capable of negotiating for form depending on the situation. Specifically, to prompt negotiation of form in conversational interaction, three approaches seem effective. First, using tasks that encourage learners to talk about specific linguistic forms is helpful (e.g., Swain \& Lapkin, 1998, 2002). Second, giving learners specific instructions before they engage in a conversation task might be effective to encourage them to negotiate for form (Swain, Brooks, \& Tocalli-Beller, 2002). Lastly, as I have discussed above, interacting with trained language teachers who are aware of the effectiveness of elicitation is helpful for learners to notice the gap and modify their inaccurate utterances (see studies on form-focused instruction, for example, Doughty \& Varela, 1998; Lightbown; 1998; Lyster, 2004; Muranoi 2000; 2001; Spada \& Lightbown, 1993).

\section{Noticing and Modified Output}

The second research question was whether learners modify their grammatically inaccurate utterances. To investigate this, first, the proportions of modified output across dyad types that initially followed inaccurate utterances were examined (see Table 5). Learners modified their erroneous utterances at the rate of $21 \%$ in learner-NS dyads and $24 \%$ in learner-learner dyads, a difference that was not significant. This indicates that learners tried to repair errors at a similar rate in both learner-learner dyads and in learner-NS dyads. Considering a lapsed modification as a learner's modification move generated by feedback, another analysis was performed: lapsed modifications of the trigger with incorporation of the feedback were compared to nonmodified output. This analysis revealed that learners' modifications responding to feedback in later turns corresponded to nonmodified output in the initial turns. In learner-NS dyads, of the 34 nonmodified output cases, learners incorporated the feedback in later turns 5 times. When they interacted with each other, of the 13 instances of nonmodified output, 10 turned into modifications in later turns. Although, due to small cell sizes, the proportions of modified output in the two types of dyads were not statistically different, it seems that learners did better in learner-learner dyads in terms of incorporating 
feedback that followed grammatical errors. Learners repaired 14 errors out of $17(82 \%)$ in learner-learner dyads and only 14 out of $43(33 \%)$ in learner-NS dyads (Table 5). Apparently, learners remembered the reformulated versions of their errors that were embedded in their learner partners' implicit feedback until later turns where they could incorporate them.

\section{Table 5. Modified output following feedback on grammatical errors across dyad types}

\begin{tabular}{lcccc}
\hline & \multicolumn{2}{c}{ Learner-NS dyads } & \multicolumn{2}{c}{ Learner-learner dyads } \\
\cline { 2 - 5 } & $\mathrm{n}$ & $\%$ & $\mathrm{n}$ & $\%$ \\
\hline Modified output & 9 & 21 & 4 & 24 \\
Nonmodified output & 34 & 79 & 13 & 76 \\
\hline \multicolumn{4}{c}{$\sqrt{ }$ added modifications in later turns } \\
\hline Modified output & 14 & 33 & 14 & 82 \\
Nonmodified output & 29 & 67 & 3 & 18 \\
\hline Total & 43 & 100 & 17 & 100 \\
\hline
\end{tabular}

The retrospection data provide further support for this finding. The participants reported that they were more careful in terms of grammatical accuracy when they were interacting with their learner partner. They explained this phenomenon in terms of their perception that NSs were more able to understand their "poor" English than their learner partner (Sato \& Lyster, 2007). In other words, learners thought they had to work harder to convey messages in learner-learner dyads. At the same time, many of the participants told me that they were able to listen to both their partner's utterances and their own utterances when they were interacting with their learner partner; thus they noticed grammatical features more in learner-learner dyads. It seems that these findings support two completely opposite claims regarding the effectiveness of recasts. On the one hand, as Lyster (2004) found, learners in the present study could not react by modifying their inaccurate utterances in response to implicit feedback provided by NSs. At the same time, as Ohta (1999) discovered, recasts provided by other learners were salient enough for learners to notice and 
successfully modify their output (see comparative studies, for instance, Lyster \& Mori, 2006; Sheen, 2004). The present study demonstrated that these differences in learners' interactional moves were determined by whom they interacted with. They were able to react to recasts more in peer interaction than in learner-NS interaction.

Most of the studies on interaction have excluded self-initiated modified output from their discourse analysis (for instance Ellis et al., 2001; Lyster \& Ranta, 1997). Following Shehadeh's (1999, 2001, 2003) studies, the present study looked at this move from the perspective of "comprehensible modified output," wherein learners could reprocess and reconstruct their interlanguage by testing their linguistic hypotheses (Swain \& Lapkin, 1995). However, whereas Shehadeh's definition of self-initiated moves includes attempts, as the word "attempt" indicates, that may end up failing to repair the error, repeating the error, or successfully modifying output, only successful repairs were investigated in the present study. This was because it seemed methodologically difficult to differentiate a learner's self-initiated lexical, syntactic, and semantic modifications from modifications that a NS would also employ as a natural discoursal move. Consequently, all instances of successful self-initiated modified output in the present study were phonological or morphosyntactic modifications, as illustrated in excerpt 3.

\section{Excerpt 3}

Daisuke: And in my picture E, the police car doesn't come, hasn't come.

The most striking difference between Shehadeh's definition and the way I operationalized this interactional move was that for him a selfinitiated attempt may generate negotiation after the attempt, whereas in the present study, if an attempt generated negotiation it was coded as a trigger. Thus, I looked at self-initiated modified output which achieved message comprehensibility or accuracy on its own.

As shown in Table 6, the difference between the two types of dyads in the amount of successful self-initiated modified output was significant. In learner-NS dyads, learners modified their output without receiving feedback 24 times, whereas they employed this move 53 times in learner-learner dyads. Thus, learners successfully modified their inaccurate utterances without feedback by themselves significantly more when they worked together. 
Table 6. Comparison of amounts of successful self-initiated modified output and repetition

\begin{tabular}{lll}
\hline & Learner-NS dyads & Learner-learner dyads \\
\cline { 2 - 3 } & $\mathrm{n}$ & $\mathrm{n}$ \\
\hline SMO & $24^{*}$ & $53^{*}$ \\
\hline Repetition & $94^{*}$ & $11^{*}$ \\
\hline
\end{tabular}

Note. $\mathrm{SMO}=$ Successful self-initiated modified output ${ }^{*} p<.05$

In the present study, successful self-initiated modified output was identified when learners noticed the gap in what they had just produced and repaired the problem on their own. This was because I was particularly interested in language learners who already possess adequate linguistic knowledge, at least in terms of reading and writing skills, and how, depending on their conversational partner, they differentially use the declarative knowledge they had gained by remembering explicit rules such as grammatical forms. Analysing the retrospection data revealed that this move was related more to their interpersonal process of language production than to the sort of linguistic exchange they engaged in interpersonally. At the same time, it was found that what constructed or constrained their intrapersonal moves was whom they interacted with. In this sense, "noticing the gap" in the present study does not fit with either Swain's (1995) or Schmidt and Frota's (1986) definitions. Swain's gap is the one that language learners find between what they can say and what they want to say. For Schmidt and Frota, language learners notice the gap when they hear a linguistic form embedded in comprehensible input that differs from what they have just produced. In the present study, learners already had sufficient knowledge of vocabulary and how the English grammar system works. What they struggled with was to access their declarative knowledge and to process it quickly to produce oral output. Thus, the gap in this case seems to exist more between what they know and what they can actually retrieve.

In excerpt 4, Shigeo notices his inaccurate utterance by himself and modifies it without receiving feedback. 


\section{Excerpt 4}

Shigeo: Ah..., next to the park, two boy, two child, two children is playing.

Reflecting on this utterance, Shigeo reported, "I was like wait! This should be plural! But now I know I should have said 'children are'" (Retrospection excerpt 3). This is a typical psychological process that learners went through. Many participants gave me similar reflections when I asked them about the utterances where successful self-initiated modified output was identified. In the present study, it was revealed that interacting with the learner partner provided them with a better context within which they could notice this gap and act upon it. As Swain (1998) raises the importance of the hypothesis testing procedure to internalize new structures and forms, this finding seems important because the nature of self-initiation in general and self-initiated modified output in particular is a representation of a language learner's attempt to develop their interlanguage.

\section{Social Relationship and Interactional Moves}

The present study investigated not only learners' quantifiable utterances but also how their perceptions of their partners tend to influence their interactional moves, which was the third research question. In the retrospective stimulated recall sessions, the learners reported the following perceptions:

1, They felt less pressure when they interacted with other learners.

2. They felt that they had more time in learner-learner dyads to plan what they were going to say.

3. They felt they were able to notice grammatical features more in learner-learner dyads than in learner-NS dyads.

4. They believed that their NS partners were capable of guessing the meanings of their utterances.

5. They felt much more comfortable communicating with their learner partner when they engaged in the task.

The relationship between their perceptions about their interlocutors and their interactional moves can be found in the analysis of repetitions. In the present study, cases where a learner repeated part of their partner's 
utterance without rising intonation were coded as repetition. In fact, none of the repetitions without rising intonation generated language-related episodes; therefore, they did not function as elicitative or reformulating interactional feedback (see Excerpt 5).

\section{Excerpt 5}

NS: And there are two men,

Taka: two men.

NS: standing next to the tow truck. OK. But there is another bus.

Taka: another bus.

Interestingly however, in the stimulated recall sessions, the participants reported that they repeated part of their partner's utterances to confirm the meaning. The argument here is that learners did not use rising intonation even when they wanted to confirm the message. Thus, they lost many opportunities to generate negotiation because of these ambiguous repetitions, which were found to be substantially more frequent in learner-NS dyads. As shown in Table 6, analysis of the repetitions revealed that learners used this move significantly more in learner-NS dyads than in learner-learner dyads. In learner-learner dyads, 11 repetitions of parts of their partner's utterances were observed whereas in learner-NS dyads 94 instances were found.

Another reason they gave me for repetitions is related to a sociocultural issue. They told me that they were repeating to show that they were listening to their NS partner. In retrospection excerpt 4, Shigeo says he was repeating his native-speaking partner because he thinks being silent would have made him appear rude:

\section{Retrospection excerpt 4}

I was repeating because I wanted to make sure that I understood my partner correctly. That's the first reason. Also, I was repeating because I wanted to let my partner know that I was listening to him. This is why I was repeating the last words quite often even when I was pretty sure that I understood him correctly. Besides, I think it's rude to be quiet all the time during the conversation.

This retrospection data seems to support Wong-Fillmore's (1979) claim that language learners often feign understanding rather than indicating a communication problem to maintain rapport with their partner, espe- 
cially with a partner who is a NS of the target language. That learners in the present study did not use rising intonation even when they wanted to confirm the message indicates in a sense that they were feigning understanding. It is interesting that this phenomenon was frequently observed in the present study, where the learners, unlike those in Wong-Fillmore's study, were not immigrant children wanting to blend into a new social environment. It also seems that the participants in the present study were aware of a well-known problem of Japanese learners of English, which is foreign language anxiety. Much research on the relationship between language anxiety and oral production has reported that Japanese EFL students are especially quiet in the classroom and, consequently, they lose opportunities to improve their speaking ability (Kess, 1996; Pite, 1996).

In addition, it was found that the perceptions summarized above also affected the other interaction patterns (for detailed analyses and discussion, see Sato \& Lyster, 2007). It was found that NSs played a dominant role throughout the task even though a two-way information exchange task was employed to avoid dominant/passive relationships. This was primarily because NSs' feedback, which mostly consisted of reformulation moves, tended to let learners either acknowledge the feedback or simply continue the conversation until NSs obtained the information they were seeking to complete the task. In contrast, when learners interacted with each other, they succeeded in creating a forum for working collaboratively together to complete the task. In response to each other's feedback, learners tried to make their output more comprehensible by generating alternatives, assessing alternatives, and applying the resulting knowledge (Foster \& Ohta, 2005; Swain \& Lapkin, 1998).

\section{Conclusion and Classroom Implications}

The present study investigated how Japanese EFL learners, who generally have a form-focused orientation, interact differently depending on their conversation partner during a communicative task. The results revealed that negotiation of form is highly unlikely to occur in this specific context, especially in learner-NS interaction. At the same time, the introspection data revealed that learners became more analytic when they talk to other learners in the sense that they were more capable of modifying their erroneous utterances through language-related episodes. It was also revealed that they were more careful to speak accurately in learnerlearner dyads. Interestingly, this perception led them to modify their erroneous utterances more. In addition, learners successfully modified 
their erroneous utterances without the provision of feedback more when they interacted with other learners than when they interacted with NSs.

Based on these findings, I recommend that peer interaction with specific instructions be integrated into classroom activities as an important source of learning, especially for improving speaking ability. It seems feasible and effective to teach students how to give feedback to each other. This is not to say that interacting with NSs of the target language is not valuable. However, it seems problematic that communicative language teaching, which upholds a glorified perspective of NSs and yet does not lend importance to teachers' didactic feedback, is seen by many as the most effective pedagogy. In many EFL contexts, especially in Asian countries, NSs are generally considered as the most important resource for language learning in classrooms. Taking into consideration that trained language teachers actually provide learners with opportunities to modify their erroneous utterances (Lyster \& Ranta, 1997), it seems significant to distinguish NSs and trained language teachers; therefore, trained language teachers including nonnative-speaking teachers are necessary in EFL classrooms.

Masatoshi Sato is an instructor of EFL in the Human International Universities and Colleges Consortium in Japan and a graduate of McGill University. His research interests include second language acquisition, interaction, and the procedualization of grammatical knowledge, especially with EFL learners.

\section{References}

Anderson, J. (1990). Cognitive psychology and its implication (3 $3^{\text {rd }}$ ed.). New York: Freeman.

Bardovi-Harlig, K., \& Dörnyei, Z. (1998). Do language learners recognize pragmatics violations? Pragmatic versus grammatical awareness in instructed L2 learning. TESOL Quarterly, 32, 233-259.

Bell, A. (1984). Language style as audience design. Language in Society, 13, 145204.

Block, D. (2003). The social turn in second language acquisition. Washington, DC: Georgetown University Press.

Canale, M., \& Swain, M. (1981). A theoretical framework for communicative competence. In A. Palmer, P. Groot, \& G. Trosper (Eds.), The construct validation of tests of communicative competence: Including proceedings of a colloquium at TESOL '79 (pp. 31-36). Washington, DC: TESOL. 
Cohen, A. (1987). Using verbal reports in research on language learning. In C. Færch \& G. Kasper (Eds.), Introspection in second language research (pp. 82-95). Clevedon, UK: Multilingual Matters.

Corder, S. (1973). The elicitation of interlanguage. In J. Svartvik (Ed.), Errata: Papers in error analysis (pp. 36-48). Lund, Sweden: CKW Geerup.

de Bot, K. (1996). The psycholinguistics of the output hypothesis. Language Learning, 46, 529-555.

DeKeyser, R. (1998). Beyond focus on form: Cognitive perspectives on learning and practicing second language grammar. In C. Doughty \& J. Williams (Eds.), Focus on form in classroom second language acquisition (pp. 42-63). New York: Cambridge University Press.

Doughty, C., \& Pica, T. (1986). "Information gap" tasks: An aid to second language acquisition? TESOL Quarterly, 20, 305-325.

Doughty, C., \& Varela, E. (1998). Communicative focus on form. In C. Doughty \& J. Williams (Eds.), Focus on form in classroom second language acquisition (pp. 114-138). New York: Cambridge University Press.

Ellis, R., Basurkmen, H., \& Loewen, S. (2001). Learner uptake in communicative ESL lessons. Language Learning, 51, 281-318.

Ericsson, K., \& Simon, H. (1984). Protocol analysis: Verbal report as data. Cambridge, MA: MIT Press.

Foster, P. (1998). A classroom perspective on the negotiation of meaning. Applied Linguistics, 19, 1-23.

Foster, P., \& Ohta, A. (2005). Negotiation for meaning and peer assistance in second language classrooms. Applied Linguistics, 26, 402-430.

Futaba, T. (2001). A task works for negotiation of meaning. JALT Applied Materials, 39-58.

Gass, S. (1997). Input, interaction, and the second language learners. Hillsdale, NJ: Lawrence Erlbaum.

Gass, S., \& Mackey, A. (2000). Stimulated recall methodology in second language research. Mahwah, NJ: Lawrence Erlbaum.

Gass, S., \& Varonis, E. (1985). Task variation and nonnative/nonnative negotiation of meaning. In S. Gass \& C. Madden (Eds.), Input in second language acquisition (pp. 149-161). Rowley, MA: Newbury House.

Gass, S., \& Varonis, E. (1989). Incorporated repairs in nonnative discourse. In M. Eisenstein (Ed.), The dynamic interlanguage: Empirical studies in second language variation (pp. 71-86). New York: Plenum Press.

Gass, S., \& Varonis, E. (1994). Input, interaction, and second language production. Studies in Second Language Acquisition, 16, 283-302.

Hawkins, B. (1985). Is an "appropriate response" always so appropriate? In S. Gass \& C. Madden (Eds.), Input in second language acquisition (pp. 162-178). Rowley, MA: Newbury House. 
Kess, A. (1996). Predictable problems of Japanese students: In-group belonging and saving face. In A. McDonald \& G. McDonald (Eds.), Intensive English Program Newsletter, 12, 8-9.

Lee, G. (1999). Positively interdependent: Developing oral fluency via task design. In D. Kluge, S. McGuire, D. Johnson, \& R. Johnson (Eds.), JALT applied materials: Cooperative learning (pp. 117-125). Tokyo: Japan Association for Language Teaching.

Lightbown, P. (1998). The importance of timing in focus on form. In C. Doughty \& J. Williams (Eds.), Focus on form in classroom second language acquisition (pp. 117-196). New York: Cambridge University Press.

Long, M. (1981). Input, interaction, and second language acquisition. Annals of the New York Academy of Science, 379, 259-278.

Long, M. (1996). The role of the linguistic environment in second language acquisition. In W. Ritchie \& T. Bhatia (Eds.), Handbook of second language acquisition (pp. 413-468). San Diego: Academic Press.

Lyster, R. (1998). Recasts, repetition, and ambiguity in L2 classroom discourse. Studies in Second Language Acquisition, 20, 51-81.

Lyster, R. (2002a). The importance of differentiating negotiation of form and meaning in classroom interaction. In P. Burmeister, T. Piske, \& A. Rohde (Eds.), An integrated view of language development: Papers in honor of Henning Wode (pp. 381-397). Trier, Germany: Wissenschaftlicher Verlag Trier.

Lyster, R. (2002b). Negotiation in immersion teacher-student interaction. International Journal of Educational Research, 37, 237-253.

Lyster, R. (2004). Differential effects of prompts and recasts in form-focused instruction. Studies in Second Language Acquisition, 26, 399-432.

Lyster, R., \& Mori, H. (2006). Interactional feedback and instructional counterbalance. Studies in Second Language Acquisition, 28.

Lyster, R., \& Ranta, L. (1997). Corrective feedback and learner uptake: Negotiation of form in communicative classrooms. Studies in Second Language Acquisition, 19, 37-66.

Mackey, A. (2002). Beyond production: Learners' perceptions about interactional processes. International Journal of Educational Research, 37, 379-394.

Mackey, A., Gass, S., \& McDonough, K. (2000). How do learners perceive interactional feedback? Studies in Second Language Acquisition, 22, 471-197.

Mackey, A., Oliver, R., \& Leeman, J. (2003). Interactional input and the incorporation of feedback: An exploration of NS-NNS and NNS-NNS adult and child dyads. Language Learning, 53, 35-66.

Mackey, A., \& Philp, J. (1998). Conversational interaction and second language development: Recasts, responses, and red herrings? Modern Language Journal, $82,338-356$. 
McDonough, K., \& Mackey, A. (2000). Communicative tasks, conversational interaction, and linguistic form: An empirical study of Thai. Foreign Language Annals, 33, 82-91.

Morris, F., \& Tarone, E. (2003). Impact of classroom dynamics on the effectiveness of recasts in second language acquisition. Language Learning, 53, 325-368.

Muranoi, H. (2000). Focus on form through interaction enhancement: Integrating formal instruction into a communicative task in EFL classrooms. Language Learning, 50, 617-673.

Muranoi, H. (2001). Focus on form: Implicit and explicit form-focused instruction incorporated into a communicative task. JALT Applied Materials, 25-36.

Nabei, T., \& Swain, M. (2002). Learner awareness of recasts in classroom interaction: A case study of an adult EFL student's second language learning. Language Awareness, 11, 43-63.

Nicholas, H., Lightbown, P., \& Spada, N. (2001). Recasts as feedback to language learners. Language Learning, 51, 719-758.

Nobuyoshi, J., \& Ellis, R. (1993). Focused communication tasks and second language acquisition. ELT Journal, 47, 203-210.

Ohta, A. (1999). Rethinking recasts: A learner-centered examination of corrective feedback in the Japanese language classroom. In J. Hall \& L. Verplaeste (Eds.), The construction of second and foreign language learning through classroom interaction (pp. 47-71). Mahwah, NJ: Erlbaum.

Panova, I., \& Lyster, R. (2002). Patterns of corrective feedback and uptake in an adult ESL classroom. TESOL Quarterly, 36, 573-595.

Pica, T. (1994). Research on negotiation: What does it reveal about second-language learning condition, processes, and outcome? Language Learning, 44, 493-527.

Pica, T. (2002). Subject-matter content: How does it assist the interactional and linguistic needs of classroom language learners? Modern Language Journal, 86, 1-19.

Pica, T., Kanagy, R., \& Falodun, J. (1993). Choosing and using communication tasks for second language instruction and research. In G. Crookes \& S. Gass (Eds.), Tasks and language learning: Integrating theory and practice (pp. 9-34). Clevedon, UK: Multilingual Matters.

Pica, T., Lincoln-Porter, F., Paninos, D., \& Linnell, J. (1996). Language learners' interaction: How does it address the input, output, and feedback needs of L2 learners? TESOL Quarterly, 30, 59-84.

Pica, T., Young, R., \& Doughty, C. (1987). The impact of interaction on comprehension. TESOL Quarterly, 21, 737-758.

Pite, D. (1996). The influence of anxiety upon achievement in EFL by Japanese students. (ERIC Document Reproduction Service No. ED432143)

Plough, I., \& Gass, S. (1993). Interlocutor and task familiarity: Effects on interactional structure. In G. Crookes \& S. Gass (Eds.), Tasks and language learning: Integrating theory and practice (pp. 35-56). Clevedon, UK: Multilingual Matters. 
Poulisse, N., Bongaerts, T., \& Kellerman, E. (1987). The use of retrospective verbal reports in the analysis of compensatory strategies. In C. Færch \& G. Kasper (Eds.), Introspection in second language research (pp. 213-229). Clevedon, UK: Multilingual Matters.

Robinson, P., Sawyer, M., \& Ross, S. (2001). Second language acquisition research in Japan: Theoretical issues. JALT Applied Materials, 3-21.

Sato, M., \& Lyster, R. (2007). Modified output of Japanese EFL learners: Variable effects of interlocutor vs. feedback types. A. Mackey (Ed.), Conversational interaction in second language acquisition: A series of empirical studies. Oxford: Oxford University Press.

Schmidt, R., \& Frota, S. (1986). Developing basic conversational ability in a second language: A case study of an adult leaner of Portuguese. In R. Day (Ed.), Talking to learn (pp. 237-326). Rowley, MA: Newbury House.

Seedhouse, P. (1997). Combining form and meaning. ELT Journal, 51, 337-344.

Sheen, Y. (2004). Corrective feedback and learner uptake in communicative classrooms across instructional settings. Language Teaching Research, 8, 263300.

Shehadeh, A. (1999). Nonnative speakers' production of modified comprehensible output and second language learning. Language Learning, 49, 627-675.

Shehadeh, A. (2001). Self- and other-initiated modified output during task-based interaction. TESOL Quarterly, 35, 433-457.

Shehadeh, A. (2003). Learner output, hypothesis testing, and internalizing linguistic knowledge. System, 31, 155-171.

Skehan, P. (1998). A cognitive approach to language learning. Oxford: Oxford University Press.

Spada, N. (1997). Form-focused instruction and second language acquisition: A review of classroom and laboratory research. Language Teaching, 30, 73-87.

Spada, N., \& Lightbown, P. (1993). Instruction and the development of questions in L2 classrooms. Studies in Second Language Acquisition, 15, 205-224.

Storch, N. (2001). How collaborative is pair work? ESL tertiary students composing in pairs. Language Teaching Research, 5, 29-53.

Storch, N. (2002). Patterns of interaction in ESL pair work. Language Learning, 52, 119-158.

Swain, M. (1985). Communicative competence: Some roles of comprehensible input and comprehensible output in its development. In S. Gass \& C. Madden (Eds.), Input in second language acquisition (pp. 235-253). Rowley, MA: Newbury House.

Swain, M. (1995). Three functions of output in second language learning. In G. Cook \& B. Seidlhofer (Eds.), Principle and practice in applied linguistics: Studies in honour of H. G. Widdowson (pp. 125-144). Oxford, UK: Oxford University Press. 
Swain, M. (1998). Focus on form through conscious reflection. In C. Doughty \& J. Williams (Eds.), Focus on form in classroom second language acquisition (pp. 64-81). Cambridge: Cambridge University Press.

Swain, M., Brooks, L., \& Tocalli-Beller, A. (2002). Peer-peer dialogue as a means of second language learning. Annual Review of Applied Linguistics, 22, 171-185.

Swain, M., \& Lapkin, S. (1995). Problems in output and the cognitive processes they generate: A step toward second language learning. Applied Linguistics, 16, 371-391.

Swain, M., \& Lapkin, S. (1998). Interaction and second language learning: Two adolescent French immersion students working together. Modern Language Journal, 82, 320-337.

Swain, M., \& Lapkin, S. (2002). Talking it through: Two French immersion learners' response to reformulation. International Journal of Educational Research, 37, 285304.

Van den Branden, K. (1997). Effects on negotiation on language learners' output. Language Learning, 47, 589-636.

Varonis, E., \& Gass, S. (1985). Nonnative/nonnative conversations: A model for negotiation of meaning. Applied Linguistics, 6, 71-90.

Welkowitz, J., Ewen, B., \& Cohen, J. (2001). Introductory statistics for the behavioural sciences (5th ed.). New York: John Wiley \& Sons.

Wilkins, D. (1999). Second language teaching. In B. Spolsky (Ed.), Concise encyclopedia of educational linguistics (pp. 656-658). Oxford: Pergamon.

Williams, J. (1999). Learner-generated attention to form. Language Learning, 49, 583-625.

Wong-Fillmore, L. (1979). Individual differences in second language acquisition. In C. J. Fillmore, D. Kempler, \& W. Wang (Eds.), Individual differences in language ability and language behavior (pp. 203-228). New York: Academic Press. 


\section{Appendix}

\section{Original retrospection excerpts from stimulated recall sessions}

\section{Retrospection excerpt 1}

ただ聞き直してるだけです。アヤちゃんが迷ってるつぽかったから。アヤちゃんの間 違いを直すつもりは全くないですよ。確認してるだけです。

Retrospection excerpt 2

ダイスケ君が“two bus”っていうから、おいおいそれは複数形だろって思って、“two buses”って言いました。これは意図的でしたね。

\section{Retrospection excerpt 3}

あ!複数形や!と思って。でも今聞けば、これchildren areですよね。

Retrospection excerpt 4

相手の単語を繰り返してたのは、まずは確認のため。それと後は、あなたのいわん としてることは分かりますよってことを示すために、聞き取れてても最後の単語を繰り 返すことはよくありましたね。だって黙ってるのも失礼でしょ。 